\title{
SiGe Power HBT Design Considerations for IEEE 802.11 Applications
}

\author{
Ningyue Jiang ${ }^{1}$, Zhenqiang $\mathrm{Ma}^{1 *}$, Pingxi $\mathrm{Ma}^{2}$, Vijay Reddy ${ }^{2}$ and Marco Racanelli ${ }^{2}$ \\ ${ }^{1}$ University of Wisconsin-Madison, Department of Electrical and Computer Engineering, \\ 1415 Engineering Drive, Madison, WI 53706, USA Phone: (608) 261-1095 mazq@engr.wisc.edu \\ ${ }^{2}$ Jazz Semiconductor, Inc., 4321 Jamboree Road, Newport Beach, CA 92660, USA
}

\begin{abstract}
SiGe power HBTs integrated in SiGe BiCMOS are developed and characterized at $2.4 \mathrm{GHz}$ for 802.11b and 5.8 GHz for 802.11a wireless LAN applications. Design considerations of ballast resistors for SiGe power HBTs at these two frequencies are investigated for both good thermal stability and high RF power performance. The investigations show that emitter ballast resistors or base ballast resistors should be judiciously used for SiGe power HBTs operating at different frequencies in order to extract the best RF performance from these devices. An RF output power of $30.8 \mathrm{dBm}$ with PAE of $50.2 \%$ at $2.4 \mathrm{GHz}$ and an output power of $27.3 \mathrm{dBm}$ with PAE of $23.6 \%$ at 5.8 $\mathrm{GHz}$ are achieved from single discrete $\mathrm{SiGe}$ power HBTs with $0.4 \mu \mathrm{m}$ emitter width, respectively. These highest performance results demonstrate the great power amplification potential of SiGe HBTs for 802.11 wireless LAN applications.
\end{abstract}

Index Terms - Heterojunction bipolar transistors, microwave power, WLAN, SiGe, ballast resistors.

\section{INTRODUCTION}

The continual vertical and lateral scaling has endowed SiGe HBTs with increasing RF performance over technology generations. Besides their capabilities in lowpower, high-speed and high level integration BiCMOS applications, SiGe HBTs also demonstrated the great potential for high-power applications in wireless communications over a wide range of operation frequencies [1-6]. These devices have begun to take the place of III-V HBTs in many RF power amplifiers. For wireless local area network (WLAN) applications, SiGe HBTs are also strong candidates to meet the requirements of IEEE $802.11 \mathrm{~b}$ and $802.11 \mathrm{a}$ standards at $2.4 \mathrm{GHz}$ and $5.8 \mathrm{GHz}$. The maximum power level is $1 \mathrm{~W}$ for $802.11 \mathrm{~b}$ standards, and $800 \mathrm{~mW}$ for 802.11 a standards in $5.75-$ $5.85 \mathrm{GHz}$ band [7]. For these high power devices, ballast resistors are usually used to ensure thermal stability. Both base ballast and emitter ballast resistors can be used for this purpose [8-9]. For 0.8-1.9 GHz frequency ranges, base ballast resistors have been widely used instead of emitter ballast resistors in order to minimize the power loss in these resistors. However, it has not been studied which ballasting scheme should be judicious employed as the power amplification frequency moves up in order to extract the maximum RF power performance from power devices at all frequencies. In this paper, we compare the role of base ballast resistor and emitter ballast emitter ballast resistors on power gain and on RF power performance of SiGe power HBTs. We also report the highest performance SiGe power HBTs, employing the proper ballast resistor schemes, operated at both $2.4 \mathrm{GHz}$ and $5.8 \mathrm{GHz}$. The results demonstrate the excellent suitability of these devices for IEEE 802.11 WLAN applications.

\section{TECHNOLOGY}

The power SiGe HBTs are manufactured using JazzSemi $0.35 \mu \mathrm{m} \mathrm{SiGe60}$ process [10]. This technology, developed for cost-effective solutions for both networking and wireless applications, offers three types of SiGe n-p-n HBTs: a $62-\mathrm{GHz} \mathrm{f}_{\mathrm{T}}, 79-\mathrm{GHz} \mathrm{f}_{\text {max }}, 2.5-\mathrm{V}$ $\mathrm{BV}_{\text {СЕo }}$ high-speed device, a $46-\mathrm{GHz}_{\mathrm{T}}, 70-\mathrm{GHz} \mathrm{f}_{\max }, 3.8-\mathrm{V}$ $\mathrm{BV}_{\text {СЕO }}$ medium-voltage device and, a $24-\mathrm{GHz} \mathrm{f}_{\mathrm{T}}, 50-\mathrm{GHz}$ $\mathrm{f}_{\max }, 6.0-\mathrm{V} \mathrm{BV}_{\text {CEO }}$ high-voltage device. It also offers $3.3-\mathrm{V}$ CMOS, high-Q inductors, metal-insulator-metal (MIM) and MIS capacitors, poly and N-well resistors and highperformance varactors. The process used here is a 4metal process. More details on the technology can be found in elsewhere $[11,12]$. The power SiGe HBTs discussed here are the high-voltage devices. The total emitter area is about $1317 \mu \mathrm{m}^{2}$. To study the effect of ballast resistors on thermal stability and RF power performance, three types of SiGe power HBTs have been implemented: 1) No-ballast HBT. 2) Emitter-ballast HBT. 3) Base-ballast HBT.

\section{DESIGN CONSIDERATIONS FOR BALLAST RESISTORS IN HIGH-POWER SIGE HBTS}

In Ref. 9, base ballast in power HBTs has been considered as the proper option in comparison to emitter ballast, because the large current flowing through emitter makes emitter ballast lose power efficiency. In this implementation, capacitors paralleled with base ballast resistors have been used to bypass high frequency signal and, therefore, to preserve high RF performance. It is noted, however, that passive components such as bypass capacitors occupy too much device area, and that parallel capacitors for base ballast are not necessary in certain operation frequencies to maintain RF performance of power HBTs, as will be discussed in the following. To simplify the discussions, only the common-emitter configuration of power SiGe HBTs is considered. The power gain $\left(\mathrm{G}_{\max }\right)$ of a common-emitter HBT in different frequency ranges can be expressed, in terms of equivalent circuit parameters, as the following [13]:

I. Low-frequency unconditionally stable region: the maximum available power gain (MAG) is flat, which is 


$$
M A G_{l}=\frac{r_{o} \beta^{2}}{4\left(r_{b}+r_{\pi}+\beta r_{e x}\right)}
$$

II. Intermediate-frequency unstable region: the maximum stable gain (MSG) rolls off with the slope of 10 $\mathrm{dB} /$ decade, which is

$$
M S G=\frac{1}{\omega C_{\mu}\left(r_{e x}+r_{e}\right)}
$$

III. High-frequency unconditionally stable region: MAG rolls off with the slope of $20 \mathrm{~dB} /$ decade, which is

$$
M A G_{h}=\frac{g_{m}}{4 \omega^{2} r_{b} C_{\mu} C_{\pi}}
$$

where, $r_{b}$ is total base resistance including pinch resistance, link resistance, extrinsic resistance and resistance of the added base ballast resistor, $r_{\mathrm{ex}}$ is external emitter resistance including added emitter ballast resistance, $\mathrm{C}_{\mu}$ is $\mathrm{BC}$ junction capacitance and $\beta$ is current gain. In addition, $r_{e}=\frac{\alpha}{g_{m}}, r_{\pi}=\frac{\beta}{g_{m}}$ and $\mathrm{g}_{\mathrm{m}}$ is transconductance.

Because the frequency of region I is usually very low, it is not of much interest for RF and microwave applications. If the operation frequency is within region II, there is an emitter resistance dependence of MSG. For bigger $r_{\text {ex }}$, MSG decreases according to Eq. 2. Thus, MSG will be degraded for the use of emitter ballast resistor. In contrast, base resistance has no effect on MSG, indicating that using base ballast resistor in this frequency region will not sacrifice MSG. Even without high-frequency bypass capacitors, the power gain performance can be well preserved in region II. Therefore, base ballast resistor should be used if the operation frequency is in this intermediate-frequency (unstable) region. If the operation frequency falls into region III, MAG will be the useful power gain. As shown in Eq. 3, MAG is dependent on base resistance $r_{b}$. Clearly, a small $r_{b}$ is desired for a high MAG. Hence, use of base ballast resistors should be avoided in this frequency range. Instead, emitter ballast should be used in this stable high-frequency region because emitter resistance does not affect MAG according to Eq. 3

\section{MEASUREMENT RESULTS}

In order to compare the dependence of power gain characteristics on ballast resistors, small-signal Sparameters were measured for three types of SiGe power HBTs: 1) no-ballast HBT, 2) emitter-ballast HBT and 3) base-ballast HBT. Their device structures are identical except for the ballast resistors. The values of ballast resistors were chosen based on the thermal stability study [14], i.e. both emitter-ballast and base-ballast HBTs are thermally stable under higher power operations. All three types of devices consist of 144 emitter fingers with $0.9 \times 10.16 \mu \mathrm{m}^{2}$ emitter area for each finger. The measured MAG/MSG curves of these three types of power SiGe HBTs are shown in Fig. 1. By comparing no-ballast and emitter-ballast HBTs, it can be seen that power gain difference between these two HBTs is only within the unstable region: MSG of emitter-ballast HBT is about $3 \mathrm{~dB}$ lower than no-ballast HBT. Their MAG curves, however, overlap exactly, indicating that emitter ballast resistors do not affect MAG, but MSG (Eq. 2). The comparison between no-ballast and base-ballast HBTs shows that the MAG curve of base-ballast HBT is lower than that of no-ballast HBT, while their MSG curves overlap. Note that the MAG/MSG curves of baseballast and emitter ballast HBTs merge at $0.34 \mathrm{GHz}$. Based on Fig. 1, for these devices, base ballast should be used below $0.34 \mathrm{GHz}$, while emitter ballast should be used above $0.34 \mathrm{GHz}$ in order to maximize the power gain values. In contrast, current gain of the three types of SiGe power HBTs is plotted in Fig. 2, showing no significant difference among all three options. This indicates that current gain is not a good indicator for HBTs in power amplification applications.

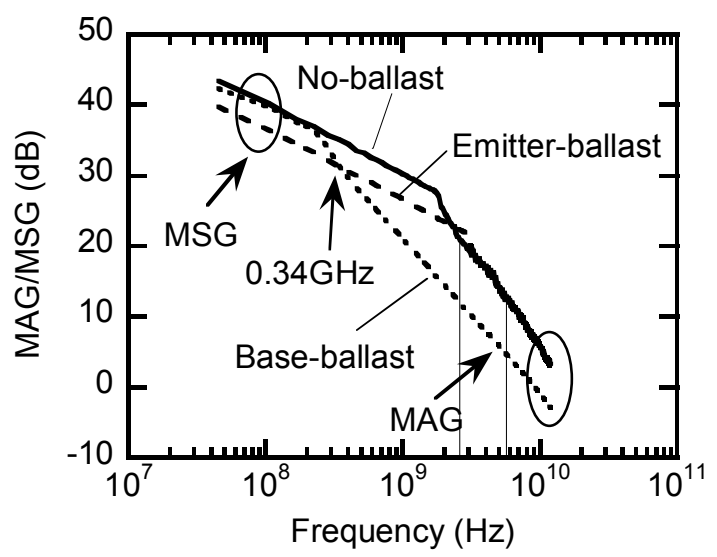

Fig. 1. Measrued MAG/MSG as a function of frequency for three types of SiGe power HBTs.

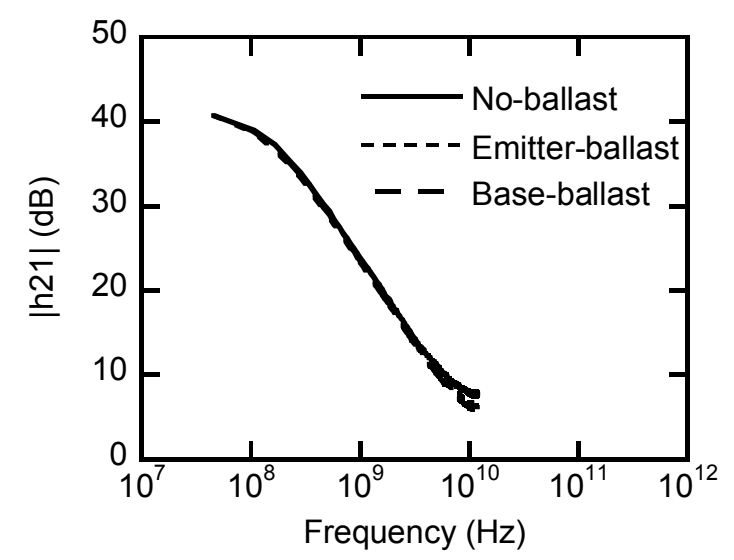

Fig. 2. Measured current gain as a function of frequency of three types of SiGe power HBTs.

On-wafer source and load pull measurements were performed using the Focus Microwaves CCMT1816 automatic tuner system under class $\mathrm{AB}$ operation at 2.4 $\mathrm{GHz}$. For good linearity, the devices were biased close to class A. The emitter-ballast SiGe HBTs were biased at $\mathrm{V}_{\mathrm{BE}}=0.81 \mathrm{~V}$ and $\mathrm{V}_{\mathrm{CE}}=5.0 \mathrm{~V}$. The base-ballast SiGe HBTs were biased at $\mathrm{V}_{\mathrm{BE}}=0.79 \mathrm{~V}$ and $\mathrm{V}_{\mathrm{CE}}=5.0 \mathrm{~V}$. 
Their quiescent collector currents are $100 \mathrm{~mA}$. The RF input power was swept from $-5 \mathrm{dBm}$ to $23 \mathrm{dBm}$. For emitter-ballast HBTs, source and load tuners were optimized for maximum output power with a source reflection coefficient of $0.854<177.0^{\circ}$ and a load reflection coefficient of $0.696<155.7^{\circ}$. The large-signal RF characteristics of an emitter-ballast HBT are shown in Fig. 3. The maximum output power of $30.8 \mathrm{dBm}$ was obtained with an associated power gain of $8.7 \mathrm{~dB}$. At the peak power-added efficiency (PAE) of $50.2 \%$, the device can deliver an output power of $29.8 \mathrm{dBm}$ with an associated power gain of $11.4 \mathrm{~dB}$. A linear power gain of $17 \mathrm{~dB}$ is exhibited by this device at low-level input power. For base-ballast HBTs, the optimized source and load reflection coefficients are $0.819<182.1^{\circ}$ and $0.697<159.7^{\circ}$ for maximum output power. The largesignal RF characteristics of the base-ballast HBT are also shown in Fig. 3 for comparison. This device delivers a maximum output power of $30.2 \mathrm{dBm}$. A maximum PAE of $40.9 \%$ was obtained when it delivers an output power of $29.8 \mathrm{dBm}$ with an associated power gain of $8.2 \mathrm{~dB}$. It exhibits a linear power gain of $12.8 \mathrm{~dB}$ when the input power level is low. From Fig. 1, it is clear that emitterballast HBTs have higher power gain than base-ballast HBTs at $2.4 \mathrm{GHz}$ (MAG frequency range), because the base ballast resistor degrades the MAG of devices in high-frequency region. The large-signal power gain measured from emitter-ballast and base-ballast HBTs is consistent with the small-signal MSG/MAG comparison. From Fig. 3, emitter-ballast HBTs show a higher power gain and hence a higher PAE than base-ballast HBTs at $2.4 \mathrm{GHz}$. Therefore, for these SiGe power HBTs, emitter ballast should be used for $2.4 \mathrm{GHz}$ applications. It is noted that the power handling capabilities of these two HBTs are the same. The output RF power of both HBTs reaches about $30 \mathrm{dBm}$.

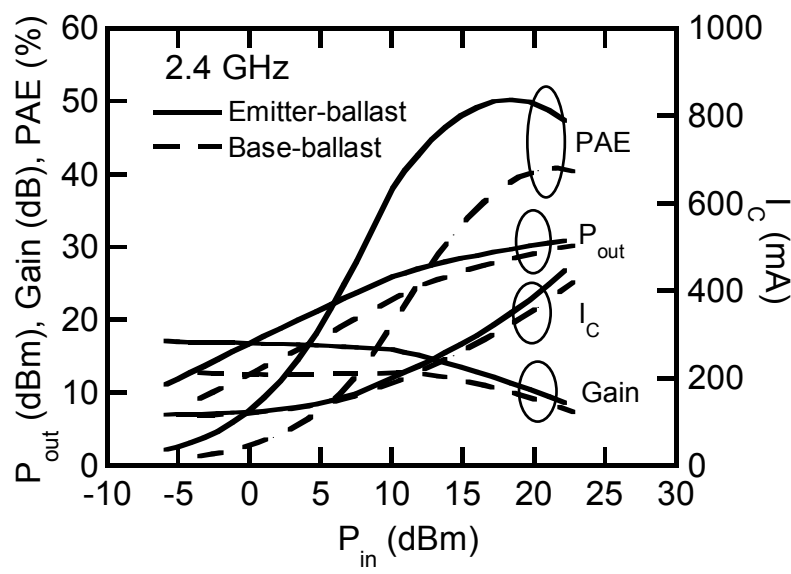

Fig. 3. Comparison of large-signal performance characteristics of emitter-ballast and base-ballast SiGe HBTs operating at $2.4 \mathrm{GHz}$, indicating the advantage of using emitter ballast resistors at this frequency.

On-wafer source and load pull measurements were also performed at $5.8 \mathrm{GHz}$ for emitter-ballast SiGe HBTs and base-ballast SiGe HBTs. The DC bias is the same as in measurement at $2.4 \mathrm{GHz}$. For emitter-ballast HBTs, a maximum output power of $27.3 \mathrm{dBm}$ was obtained when the source and load reflection coefficients were optimized to $0.825<184.9^{\circ}$ and $0.806<166.6^{\circ}$, respectively. Fig. 4 shows the large-signal RF performance characteristics of an emitter-ballast SiGe power HBT operating at $5.8 \mathrm{GHz}$. It exhibits a linear power gain of $9.9 \mathrm{~dB}$ and a maximum PAE of $23.6 \%$. For base-ballast HBTs, the optimized source and load reflection coefficients are $0.765<187.3^{\circ}$ and $0.788<165.7^{\circ}$ for maximum output power. The largesignal RF characteristics for a base-ballast HBT are also shown in Fig. 4 for comparison. A maximum output power of $25.7 \mathrm{dBm}$ with an associated power gain of 4 $\mathrm{dB}$ was obtained. The linear power gain is $4.5 \mathrm{~dB}$ and the maximum PAE is $14.0 \%$. Again, from Fig. $1,5.8 \mathrm{GHz}$ falls in the high-frequency (MAG) region for both emitter-ballast and base-ballast HBTs. Emitter-ballast HBTs have sufficiently high MAG while base-ballast HBTs exhibit very low power gain at $5.8 \mathrm{GHz}$. Therefore, emitter-ballast HBTs provide higher linear power gain and higher PAE than base-ballast HBTs, which is confirmed by Fig. 4. Thus, emitter ballast is also the appropriate choice for $5.8 \mathrm{GHz}$ applications.

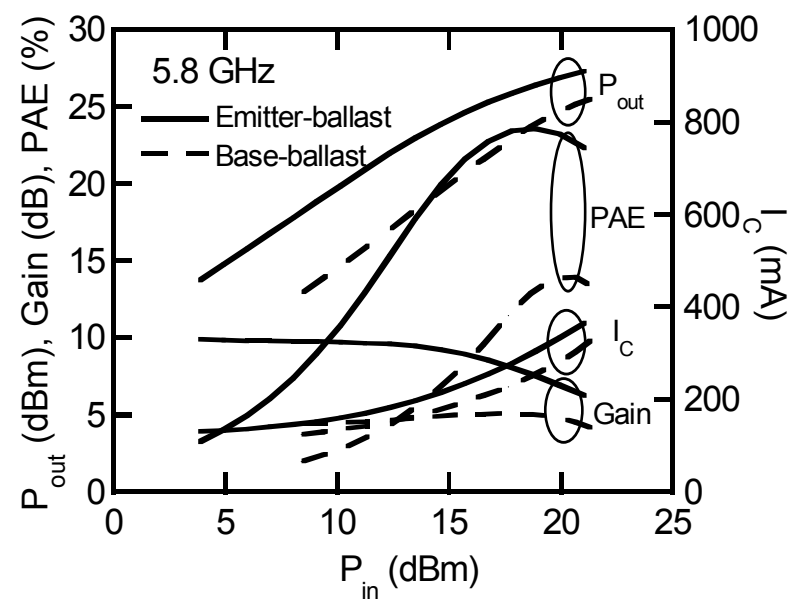

Fig. 4. Measured large-signal performance of emitter-ballast and base-ballast SiGe HBTs at $5.8 \mathrm{GHz}$, indicating the higher performance achieved using emitter ballast resistors at this frequency.

For comparison, a summary of the reported RF power levels versus frequency for single SiGe power HBTs and power amplifier modules are shown in Fig. 5. It is seen that, regardless the room of further improvement (e.g., by further improving $\mathrm{G}_{\max }$ ), the state-of-the-art performance of SiGe HBTs operating at $2.4 \mathrm{GHz}$ and $5.8 \mathrm{GHz}$ has been achieved in this study.

This study is based on JazzSemi high breakdown voltage $\mathrm{SiGe} \mathrm{HBTs}$. As described above, these devices exhibit about $50 \mathrm{GHz} \mathrm{f}_{\max }$ for single- or few-finger configurations. As more fingers are paralleled in one device, the value of $f_{\max }$ (thus power gain) degrades even if no ballast resistors are used, as commonly observed. The power gain curves (Fig. 1) actually dictates which ballast resistor scheme should be used. If the power gain curve shown in Fig. 1 can be moved to higher gain values (e.g., via further lateral downscaling) such that the operation frequency falls into the MSG region, base ballast resistors may be used for $2.4 \mathrm{GHz}$ power 
amplification under common-emitter configuration. Further improvement of $f_{\max }$, could also make baseballast resistors suitable for $5.8 \mathrm{GHz}$ power amplification.

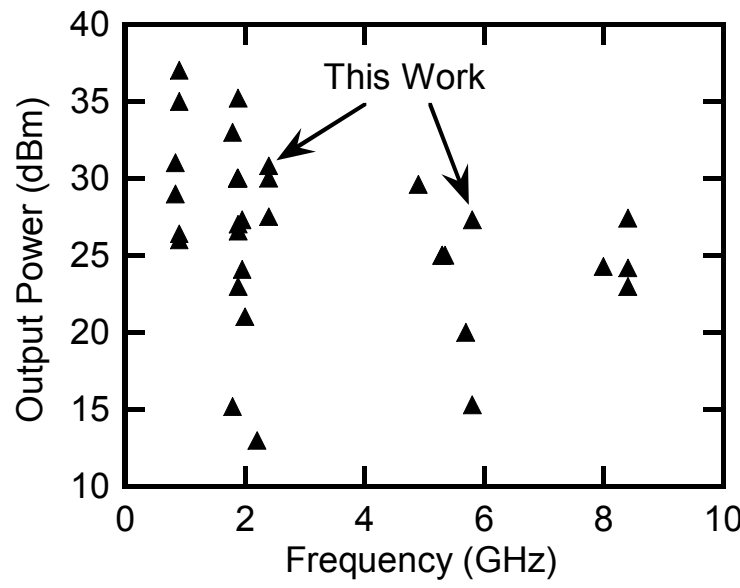

Fig. 5. Total output power versus frequency from single-chip discrete devices or power amplifiers for SiGe HBTs.

\section{CONCLUSION}

Design considerations of $\mathrm{SiGe}$ power HBTs for IEEE 802.11 applications has been discussed. The impact of emitter ballast and base ballast resistors on RF power performance of SiGe power HBTs has been investigated. To achieve both thermal stability and high power performance using high breakdown SiGe HBTs (single finger exhibiting $50 \mathrm{GHz} \mathrm{f}_{\max }$ ), emitter-ballast is the judicious choice for $2.4 \mathrm{GHz}$ and $5.8 \mathrm{GHz}$ applications when the devices are operated in the stable, high frequency range (MAG). Load-pull measurement of an emitter-ballast SiGe HBT with an emitter area of $144 \times 0.9 \times 10.16 \mu \mathrm{m}^{2}$ demonstrated $30.8 \mathrm{dBm}$ output power with an associated gain of $8.7 \mathrm{~dB}$ and a maximum PAE of $50.2 \%$ at $2.4 \mathrm{GHz}$. At $5.8 \mathrm{GHz}, 27.3 \mathrm{dBm}$ output power with an associated gain of $6.3 \mathrm{~dB}$ and a maximum PAE of $23.6 \%$ was achieved. This study also demonstrated the great potential of SiGe power HBTs for power amplification in WLAN applications.

\section{ACKNOWLEDGEMENT}

The authors are grateful for the support provided by NSF under Grant No. ECS 0323717.

\section{REFERENCES}

[1] J. Zhang, H. Jia, P. Tsien, and T. Lo, "Emitter-ballastingresistor-free $\mathrm{SiGe}$ microwave power heterojunction bipolar transistor," IEEE Electron Device Letters, vol. 20, no. 7, pp. 326-328, July 1999.

[2] A. Schuppen, S. Gerlach, H. Dietrich, D. Wandrei, U. Seiler, and U. Konig, "1-W SiGe power HBT's for mobile communication," IEEE Microwave and Guided Wave Letters, vol. 6, no.9, pp. 341-343, Sep. 1996.

[3] J. N. Burghartz, J. Plouchart, K.A. Jenkins, C.S. Webster, and M. Soyuer, "SiGe power HBT's for low-voltage, highperformance RF applications," IEEE Electron Device Letters, vol. 19, no. 4, pp. 103-105, Apr. 1998.

[4] N. Tanzi, J. Dykstra, and K. Hutchinson, "A 1-W doubly balanced $5 \mathrm{GHz}$ flip-chip SiGe power amplifier," in IEEE Radio Frequency Integrated Circuits (RFIC) Symposium, Philadelphia, PA, June 2003, pp. 141-144.

[5] A. Keerti and A. Pham, "SiGe power devices for 802.11a wireless LAN applications at $5 \mathrm{GHz}$, , Electronics Letters, vol. 39, no. 16, pp. 1218-1220, Aug. 2003.

[6] Z. Ma, S. Mohammadi, P. Bhattacharya, L.P.B. Katehi, S.A. Alterovitz, and G.E. Ponchak, "High power X-band (8.4GHz) SiGe/Si heterojunction bipolar transistor," Electronics Letters, vol. 37, no. 12, pp. 790-791, June 2001.

[7] IEEE Std 802.11a/b

[8] G.-B. Gao, M.S. Unlu, H. Morkoc, and D. Blackburn, "Emitter ballasting resistor design for, and current handling capability of $\mathrm{AlGaAs} / \mathrm{GaAs}$ power heterojunction bipolar transistors," IEEE Trans. Electron Devices, vol. 38, no. 2, pp. 185-196, Feb. 1991.

[9] W. Liu, A. Khatibzadeh, J. Sweder, and H.-F. Chau, "The use of base ballasting to prevent the collapse of current gain in $\mathrm{AlGaAs} / \mathrm{GaAs}$ heterojunction bipolar transistors," IEEE Trans. Electron Devices, vol. 43, no. 2, pp. 245-251, Feb. 1996.

[10] http://www.jazzsemi.com/process technologies/sige.shtml

[11] M. Racanelli and P. Kempf, "SiGe BiCMOS technology for communication products," Proceedings of the IEEE Custom Integrated Circuits Conference, 2003, pp. 331334.

[12] M. Racanelli, et al., International Electron Devices Meeting Tech. Digest, 2001, pp. 336-339.

[13] Z. Ma and N. Jiang, "On the operation configurations of SiGe HBTs based on power gain analysis," IEEE Trans. Electron Devices, vol. 52, no. 2, pp. 248-255, February 2005.

[14] N. Jiang, Z. Ma, G. Wang, P. Ma and M. Racanelli, "3-W SiGe power HBTs for wireless applications," Elsevier Science: Materials Science in Semiconductor Processing, in press. 